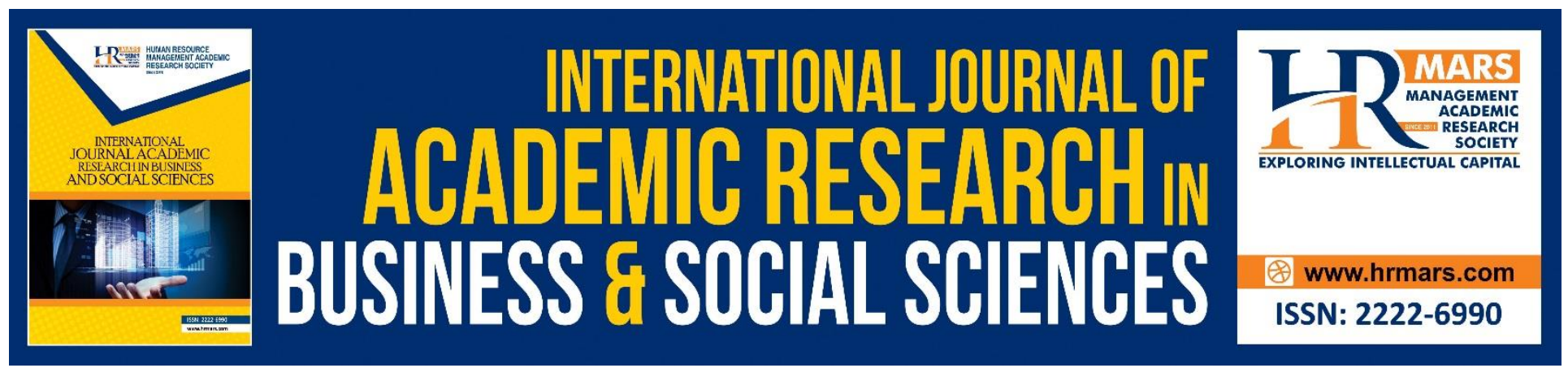

\title{
The Impact of the Board of Directors Characteristics on the Completeness of Financial Reports in Jordan
}

\author{
Mithkal Hmoud Salem Alqaraleh, Norsiah Ahmad
}

To Link this Article: http://dx.doi.org/10.6007/IJARBSS/v8-i11/4891

DOI: $10.6007 /$ IJARBSS/v8-i11/4891

Received: 03 Oct 2018, Revised: 03 Nov 2018, Accepted: 16 Nov 2018

Published Online: 24 Nov 2018

In-Text Citation: (Alqaraleh \& Ahmad, 2018)

To Cite this Article: Alqaraleh, M. H. S., \& Ahmad, N. (2018). The Impact of the Board of Directors Characteristics on the Completeness of Financial Reports in Jordan. International Journal of Academic Research in Business and Social Sciences, 8(11), 151-160.

\section{Copyright: (C) 2018 The Author(s)}

Published by Human Resource Management Academic Research Society (www.hrmars.com)

This article is published under the Creative Commons Attribution (CC BY 4.0) license. Anyone may reproduce, distribute, translate and create derivative works of this article (for both commercial and non-commercial purposes), subject to full attribution to the original publication and authors. The full terms of this license may be seen at: http://creativecommons.org/licences/by/4.0/legalcode

Vol. 8, No. 11, 2018, Pg. 151 - 160

Full Terms \& Conditions of access and use can be found at http://hrmars.com/index.php/pages/detail/publication-ethics 


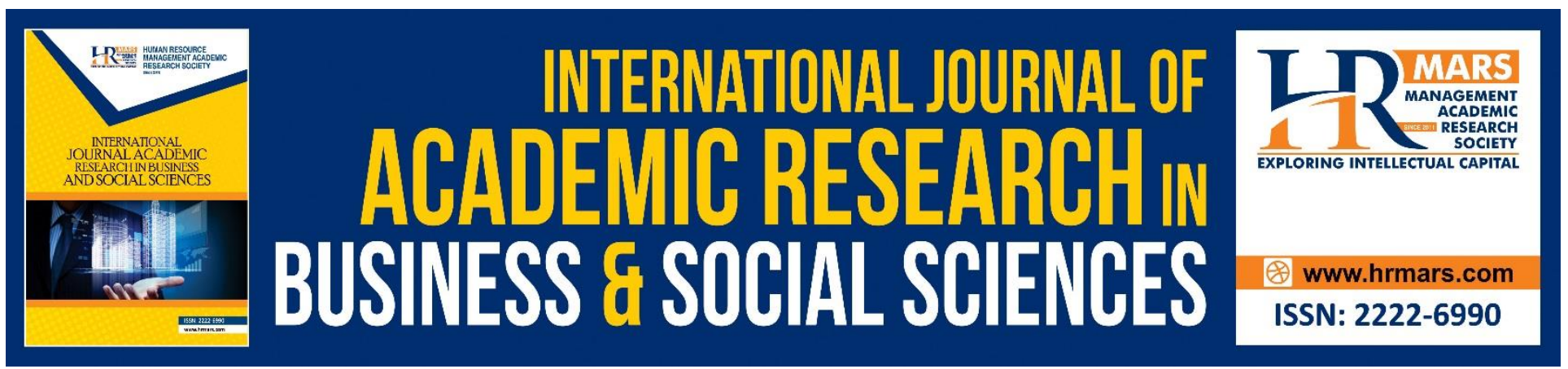

\title{
The Impact of the Board of Directors Characteristics on the Completeness of Financial Reports in Jordan
}

\author{
${ }^{1}$ Mithkal Hmoud Salem Alqaraleh, ${ }^{2}$ Norsiah Ahmad \\ ${ }^{1,2}$ Faculty of Economics and Management Science, Universiti Sultan Zainal Abidin,23100, \\ Terengganu, Malaysia \\ Email: ${ }^{1}$ mithkalhmoud@yahoo.com
}

\begin{abstract}
The study examined the effect of board of directors on completeness of financial reports of listed companies in Jordan. The study used correlational research design. The data which collected from the published annual financial reports of 172 companies listed in Jordan. The data collected was analyzed using STATA software, and the result showed that there is a positive and significant relationship between board of director (board size, board independence and leadership structure) and completeness of financial reporting. In addition, there is a positive role for the board of directors to oversee the preparation and publication of financial reports. The study hereby recommend that companies to disclose all the items that must be in the annual financial reports as this has become necessary in view of their impact on investor decisions.
\end{abstract}

Keywords: Board Of Directors, Financial Reports, Jordan, Disclosure, Completeness

\section{Introduction}

As indicated by Accounting Principle Board of America in its in announcement No. 4 statement 'completeness' implies that all the information that is reasonably needed to fulfill the requirement of the other qualitative objectives should be reported. along the qualitative characteristics of financial statements; like target, should be based heavily upon the needs of users of the data, information is useless without it is relevant to investor's decision. (Sharma, 2014).

Moreover, the accounting information must be complete from the point of view of statutory necessities and materiality. The users of accounting must be provided with full information for that they may make the right decisions (Bhattar, 1995). While, completeness is relative because financial statements cannot display everything. To try to include in financial reporting everything that any possibility user might want would not be cost beneficial and might conflict with other desirable characteristics, such as understandability. (Anonymous, 2006) Thus information disclosed by the financial reporting must be complete within the bounds of materiality and cost (Gupta and Mehra, 2002). 
When financial information to be complete, unbiased, and free from blunder,, the financial information to be faithfully represented (Weygandt, Kimmel, and Kieso, 2012). However, if information is not complete, the users external or internal of financial statements are not able to make right assessments of the data. The non completeness can mislead the users to take decisions on untrue or false information (Kieso et al. 2012).

In Jordan, Zoubi and Zoubi, (2012) found the amount of disclosed financial information in $\mathrm{n}$ the Jordanian firms is not enough. Also the companies did not disclose all items, where in 2014, 76 out of 255 companies did not provide full disclosure of items under instructions in 2017 (JSC, 2015).

From a investors point of view, maybe one of the most important factors affecting the safety of the financial reports include the board of directors. Boards of directors, among other tasks, are charged with observing and disciplining senior management, and lending convention typically require that boards od directors supply audited financial statements to the company's creditors (DeFond and Jiambalvo,1994; Dichev and Skinner, 2002). In this study we will examine the impact of the Board of Directors characteristics on the Completeness of financial reports in Jordan. we assume a significant relationship exist between the board of directors and the completeness of the financial reports.

\section{Background and Literature Review}

There are many of researches which emphasized the importance of financial information in published annual reports for investment and accounting. Ho and Wong (2003) stated how information is shared between the participants deeply impact the capital markets function. In business activities, investors require timely manner and right information to reach efficient decisions. This type of information can be collected by many ways, and one of the most important resources is the company's annual reports. The most important role of annual reports is to provide relevant, useful and reliable financial information to shareholders, investors and other about the financial position and business performance as well as its future prospects to help users in take decision. The information that has been provide through annual reports towards their investors and stakeholders includes two types: mandatory and voluntary information and mandatory disclosure is of more importance. Compulsory disclosure is a basic market demand for information that is required by regulatory bodies and has been planned at national or regional level by professional organizations or government authorities. On the opposite, company's voluntary disclosure, being in excess of requirements, represents frees choices on the part of managers to provide information to users of the annual reports (Yuen et al.,2009). Flack and Douglas (2007) underlined that annual reports were known as the annual reporting conduct of a company's and it has ability to get better the perceptions of responsibility among stakeholders and the wider community. As well, information disclosure by annual reports is a strategic tool, which can enhance the company's ability in raising capital at the lowest possible cost (Healy and Palepu, 2001).

However, Yuen et al. (2009) have shown that, the annual reports have provided insufficient information to the users. Nevertheless, Hook et al. (2002) found that in actuality numerous annual reports introduce limited quantity of information. A lot of voluntary items, which stakeholders and investors believe to be significant, are not disclosed in the annual reports. So, the convention between the significance of relative items ranked by stakeholders and the actual level of disclosure was few and there is an occasion for extend the extent and improving the quality of disclosure 
information in annual reports of listed firms. This study has involved considering to the needs of disclosure information of users in comparison with the viewpoints of suppliers. It has too tested the gap between the Financial Analysts' requirements and Financial Managers' viewpoints of information disclosure with the meeting ability of ready information in the Vietnamese non-financial listed firm's annual reports.

Researchers have recognized the board of directors as the most significant control mechanism in a firms internal governance temple (Fama and Jensen, 1983a and 1983b). For effective board must monitor financial discretion and confirm the accounting choices made through management are useful (NYSE, 2002).

The capacity of the board of directors to action as an effective control mechanism is dependent upon its independence from management (Beasley, 1996; Dechow et al. 1996). From an agency theory perspective, independent directors are predictable to provide shareholders greater protection in control management (Baysinger and Butler, 1985). This larger monitoring ability can be attributed to the incentive to uphold their reputation in the external markets (Fama and Jensen, 1983a and 1983b). Also the governance-specific influences we control for are the proportion of outsiders on the board of directors, size of board, and whether the same individual serves as both chief executive officer (CEO) and chairman of the board. Previous Studies suggests that smaller boards are more effective at fulfilling a controlling action whereas big boards are easier for the CEO to control (Jensen, 1993; Beasley, 1996).

Beasley (1996) finds that the presence of independent directors on the board of director lessens the probability of financial statement fraud. Other researchers report that firms with a big proportion of non-executive directors on the board of director are low likely to be subject to enforcement actions for violating GAAP (Dechow et al., 1996).

Board size is also possibly related to directors' ability to control and monitor managers (Jensen, 1993; Lipton and Lorsch, 1992), though the way of influence is non-clear. Some researchers find a positive relation between the number of directors and both performance of company (Chiang, 2005; Haniffa and Hudaib, 2006) and control of board (Williams et al., 2005; Anderson et al., 2004). It is argued that larger boards possess more expert skills and are better equipped to control management (Williams et al. 2005).

Another board characteristic associated is the separation of the roles of (CEO) and board chair. Corporate governance assume that a board of directors ability to implement a control role is weakened when the CEO is also the chairperson of the board (Standards Australia International, 2003; ASX, 2007; Cadbury Committee, 1992). The appointment of the CEO to the board chair is likely to lead to a concentration of power (Beasley, 1996) and possibility conflicts of interest, reducing the level of control. Forker (1992) found that separation of the roles of CEO and board chair was positively connected with the disclosure of level. However, Coulton et al. (2001) found no relationship between the separation of CEO and board chair and the level of disclosure.

\section{Methodology}

Data used in this study has been obtained from published annual reports, With regards to data analysis, this study has used various statistical analyses to obtain meaningful information including Statistics data analysis package (STATA). 
INTERNATIONAL JOURNAL OF ACADEMIC RESEARCH IN BUSINESS AND SOCIAL SCIENCES Vol. 8, No. 11, Nov, 2018, E-ISSN: 2222-6990 @ 2018 HRMARS

In this study, all companies listed on the Amman Stock Exchange were selected excluding the banks because banks have a different private law. Initially, 197 companies qualified for the study; the number declined after the exclusion of companies that were newly listed in 2014, 2015 and 2016. Companies which were newly listed in that three -year period did not have complete data as this study used continuous data from 2014 to 2016. This resulted in a final population of 172 companies. The variables were measured according to Table 1.

\begin{tabular}{|l|l|l|}
\hline \multicolumn{1}{|c|}{ variable } & coding & \multicolumn{1}{c|}{ description } \\
\hline Completeness & COMP & 1 If incomplete disclosure; 0 otherwise \\
\hline Board size & BS & $\begin{array}{l}\text { Determining the total number of directors on the board for each } \\
\text { accounting year }\end{array}$ \\
\hline $\begin{array}{l}\text { Board } \\
\text { independence }\end{array}$ & $\mathrm{BI}$ & $\begin{array}{l}\text { The total number of independent directors on the board divided by } \\
\text { the total number of board members. }\end{array}$ \\
\hline $\begin{array}{l}\text { leadership } \\
\text { structure }\end{array}$ & LS & $\begin{array}{l}\text { 1 if the positions of chairman and CEO are held by different persons } \\
\text { 0 otherwise. }\end{array}$ \\
\hline
\end{tabular}

\section{Results}

\section{Table 1: Measurement of variables}

The results show that the average board size (BS) for the sample of firms from the comp models is 5.929976 (Table 2). A study from the UK, Peasnell et al., (2005) also repeated board sizes are also reported for Jordanian firms with average of 8.01) with reference to board independence (BI), average values for which are shown in Table (2), The independent measure a Less proportion of the board of directors than insiders, with average values of 5.929976 in the Completeness (comp). This correspond to studies by Alghamdi, (2012) (for Saudi Arabia), The Jordan corporate governance policies code stipulates that it should not allow for the board of directors' chairman to occupy any another executive position in the same firm simultaneously such as, the general manager position. Correspondingly, a variable was created to investigate this issue which is called Leadership structure (LS). Table 2 the mean value 0.8000969 .

\begin{tabular}{|c|c|c|c|c|c|}
\hline Variable & Obs & Mean & Std. Dev. & Min & Max \\
\hline comp & 172 & 0.8139535 & 0.3461649 & 0 & 1 \\
\hline BS & 172 & 5.929976 & 1.838415 & 8.10323 & 9.530713 \\
\hline BI & 172 & 2.757752 & 1.458581 & 0 & 7.333333 \\
\hline LS & 172 & 0.8000969 & .7177571 & 0 & 4 \\
\hline
\end{tabular}

Table2: Descriptive Analysis 
As shown in the Table 3, all correlation coefficient values between the variables are less than 0.9. Hair et al. (2010) recommended that the correlation coefficient values above 0.90 would be a revealing of multicollinearity problem. Therefore, this study showed that the collected data revealed no multicollinearity problems.

\begin{tabular}{|c|c|c|c|c|}
\hline & comp & BS & BI & LS \\
\hline comp & 1.00 & & & \\
\hline BS & 0.0291 & 1.00 & & \\
\hline BI & $0.4227^{*}$ & -0.0158 & 1.00 & \\
\hline LS & $0.7990^{*}$ & 0.0083 & $0.3865^{*}$ & 1.00 \\
\hline
\end{tabular}

Table3: Correlation Analysis

The study shows that table 4 revealed the results of the Model standardize regression analysis. The P-value are given in bracket. The results showed that the coefficients for BS, BI and LS and Constant $(\mathrm{C})$ are positive and significant at $1 \%$ and $5 \%$ level of significance. The signs of all the variables are line with the theoretical predictions. Also, the direct relationship between $\mathrm{BS}, \mathrm{BI}$ and LS, and Comp indicated that $1 \%$ increased of BS, BI and LS will leads to $0.489 \%, 0.044 \%$ and $0.953 \%$, increased of Comp in the Jordan respectively.

\begin{tabular}{|c|c|c|}
\hline \multicolumn{3}{|c|}{ Dependent Variables Comp } \\
\hline $\begin{array}{c}\text { Independent } \\
\text { variables }\end{array}$ & Coefficients & P-value \\
\hline $\mathrm{BS}$ & $0.489^{*}$ & $(0.000)$ \\
\hline $\mathrm{BI}$ & $0.044^{* *}$ & $(0.048)$ \\
\hline $\mathrm{LS}$ & $0.953^{*}$ & $(0.002)$ \\
\hline $\mathrm{C}$ & $0.532^{*}$ & $(0.000)$ \\
\hline \multicolumn{3}{|c|}{ Diagnostics Test } \\
\hline R2 & 0.66 & \\
\hline Adjusted R2 & 0.53 & \\
\hline $\begin{array}{c}\text { Serial Correlation } \\
\text { Normality }\end{array}$ & 0.112 & 0.217 \\
\hline $\begin{array}{c}\text { Heteroskedasticit } \\
\text { y }\end{array}$ & 0.132 & 0.192 \\
\hline
\end{tabular}

Notes: $*, * *$ Denotes rejection of the null hypothesis at $1 \%$ and $5 \%$ significance level.

Table 4 Standardize Regression Analysis

The result showed positive moderating effect on board of director ( Board size, Board independence and Leadership structure ) and Completeness of financial reports. The most important motives for the financial markets is to return customer confidence of investors, shareholders and management of companies in those markets in order to keep away from failures due to the inaccuracy of the data and accounting information and the lack of transparency and accountability in 
INTERNATIONAL JOURNAL OF ACADEMIC RESEARCH IN BUSINESS AND SOCIAL SCIENCES

Vol. 8, No. 11, Nov, 2018, E-ISSN: 2222-6990 C 2018 HRMARS

financial reporting. The consequence of completeness of financial reports affects the capability of prediction for all the information and the behavior of the investors .

\section{Conclusion and Recommendations}

The study investigated the effect of board of directors on completeness of financial reports The study examined board of directors by board size, board independence and leadership structure, as independent variables, and found is a positive and significant relationship between board of director and completeness of financial reporting. In addition, there is a positive role for the board of directors to oversee the preparation and publication of financial reports. This study also revealed the existence of some Jordanian companies that do not disclose full mandatory items, which leads to misleading the investor and not to make an investment decision correctly. In addition, this study al found so lack of studies related to the completeness of financial reports thus hereby recommend that companies to disclose all the items that must be in the annual financial reports that become necessary in view of their impact on investor decisions. This study also recommend that future researchers focus on the relationship between the board of directors and financial reports for their comparisons with the results of this study.

\section{The Contribution}

This study contributes to knowledge the impact of the Board of Directors characteristics on the Completeness of financial reports in Jordan, This study is the first of its kind in Jordan, where the researcher did not find any study between Board of Directors characteristics Completeness of financial reports.

\section{References}

Alghamdi, S., \& Ali, L. (2012). Investigation into earnings management practices and the role of corporate governance and external audit in emerging markets: Empirical evidence from Saudi listed companies (Doctoral dissertation, Durham University).

Anderson, R. C., Mansi, S. A. and Reeb, D. M. (2004). Board characteristics, accounting report integrity, and the cost of debt, Journal of Accounting and Economics 37, 315-342.

Anonymous (2006). Conceptual Framework for financial reporting: Preliminary Views, Financial Accounting Standards Board (FASB) of the Financial Accounting Foundation, No. 1260-001.

Australian Securities Exchange (ASX) Corporate Governance Council, (2007). Corporate governance principles and recommendations, 2nd edition (ASX, Sydney)

Baysinger, B., and Butler, H. (1985). Corporate governance and the board of directors: Performance effects of changes in board composition, Journal of Law, Economics, \& Organization 1, 101-124.

Beasley, M. S. (1996). An empirical analysis of the relation between the board of director composition and financial statement fraud, The Accounting Review 71, 443-465.

Bhattar, M. M. (1995). Corporate Published Accounting Information and Investors (p. 6). ISBN-81900422-9-7, Books Treasure Jodhpur, India.

Cadbury Committee (Committee on the Financial Aspects of Corporate Governance (Sir Adrian Cadbury, chair), 1992, Report (Gee and Company Ltd, London). 
INTERNATIONAL JOURNAL OF ACADEMIC RESEARCH IN BUSINESS AND SOCIAL SCIENCES Vol. 8, No. 11, Nov, 2018, E-ISSN: 2222-6990 @ 2018 HRMARS

Chiang, H-T. (2005). An empirical study of corporate governance and corporate performance, Journal of American Academy of Business 6, 95-101.

Coulton, J., C. James, and S. Taylor, (2001). The effect of compensation design and corporate governance on the transparency of CEO compensation disclosures, Working Paper (University of Technology, Sydney).

Dechow, P.M., Sloan, R.G. and Sweeney, A. P. (1996). Causes and consequences of earnings manipulation: An analysis of firms subject to enforcement by the SEC', Contemporary Accounting Research 13, 1-36.

DeFond, M. L. \& Jiambalvo, J. (1994). Debt covenant violation and manipulation of accruals. Journal of accounting and economics, 17(1-2), 145-176.

Dichev, I. D. \& Skinner, D. J. (2002). Large-sample evidence on the debt covenant hypothesis. Journal of accounting research, 40(4), 1091-1123.

Fama, E. F. and Jensen, M. (1983a). Separation of ownership and control, Journal of Law and Economics 26, 301-325.

Fama, E. F. and Jensen, M. (1983b), Agency problems and residual claims, Journal of Law and Economics 26, 327-349.

Flack, T., Douglas, E. (2007). The role of annual reports in a system of accountability for public fundraising charities, PhD Dissertation, Queensland University of Technology.

Forker, J.J. (1992). Corporate governance and disclosure quality, Accounting and Business Research 22, 111-124.

Gupta, S.K. and Mehra, A. (2002). Contemporary Issues in Accounting, ISBN- 81- 272-0389-0, p.1.

Hair, J. F., Black, W. C., Babin, B. J., \& Anderson, R. E. (2010). Multivariate data analysis: A global perspective (8th ed.). New Jersey: Pearson.

Haniffa, R., and Hudaib, M. (2006). Corporate governance structures and performance of Malaysian listed companies, Journal of Business Finance and Accounting 33, 1034-1062.

Healy, P. M., \& Palepu, K. G. (2001). Information asymmetry, corporate disclosure, and the capital markets: A review of the empirical disclosure literature. Journal of accounting and economics, 31(13), 405-440.

Ho, S.S.M., Wong, K.S. (2003). Preparers' perceptions of corporate reporting and disclosure. International Journal of Disclosure and Governance 1:1, 71-81.

Hooks, J., Coy, D., \& Davey, H. (2002). The information gap in annual reports. Accounting, Auditing \& Accountability Journal, 15(4), 501-522.

Jensen, M. C., (1993). The modern industrial revolution, exit, and the failure of internal control systems, Journal of Finance 48, 831-880.

JSC. (2015). Jordan securities Commission. Annual report. Amman Jordan http://www.jsc.gov.jo/library/635995107208802178.pdf.

Lipton, M. and Lorsch, J. (1992). modest proposal for improved corporate governance, The Business Lawyer 48 (November), 59-77.

New York Stock Exchange Corporate Accountability and Listing Standards Committee (NYSE), 2002, Report, (NYSE, New York). 
Peasnell, K. V., Pope, P. F., \& Young, S. (2005). Board monitoring and earnings management: do outside directors influence abnormal accruals? Journal of Business Finance \& Accounting, 32(7-8), 1311-1346.

Sharma, A. (2014). Financial Reporting in Division I College Athletics (Doctoral dissertation, The University of Mississippi).

Standards Australia International, 2003, AS 8000 - 2003, Australian standard - good governance principles, (Standards Australia International, Sydney).

Weygandt, J. J., Kimmel, P. D., \& Kieso, D. E. (2012). Managerialaccounting. Singapore: John Wiley\&Sons.

Williams, R.J., Fadil, P.A. and Armstrong, R.W. (2005). Top management team tenure and corporate illegal activity: The moderating influence of board size, Journal of Managerial Issues 17, 479-493.

Yuen, C.Y., Liu, M., Zhang, X., Lu, C. (2009). A case study of voluntary disclosure by Chinese enterprises. Asian Journal of Finance and Accounting 1:2, 118-145. 